
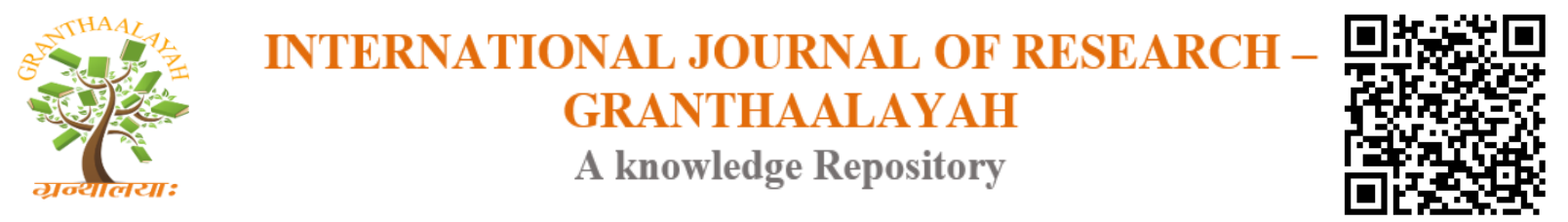

Science

\title{
USE OF THIAMETHOXAM, ASSOCIATED WITH INSECT POPULATIONS IN PAPAYA (Carica Papaya Linnaeus) CULTIVATION
}

\author{
Juan Valente Megchún-García ${ }^{1}$, María del Refugio Castañeda-Chávez ${ }^{* 2}$, Daniel Arturo \\ Rodríguez-Lagunes ${ }^{1}$, Jacel Adame-García ${ }^{3}$, Joaquín Murguía-González ${ }^{1}$, Fabiola Lango- \\ Reynoso $^{2}$, Otto Raúl Leyva-Ovalle ${ }^{1}$ \\ ${ }^{1}$ Universidad Veracruzana; Faculty of Biological and Agricultural Sciences; Región Orizaba- \\ Córdoba. Camino Peñuela-Amatlán s/n Peñuela, Municipio de Amatlán de los Reyes, Veracruz, \\ México. C. P. 94945 \\ 2 Tecnológico Nacional de México/Instituto Tecnológico de Boca Del Río. Km 12 Carretera \\ Veracruz-Córdoba, Boca del Río, Veracruz. México C.P. 94290 \\ ${ }^{3}$ Tecnológico Nacional de México/Instituto Tecnológico de Úrsulo Galván. Km 4.5. Carretera \\ Cardel-Chachalacas, CP. 91667, Úrsulo Galván, Veracruz, México
}

\begin{abstract}
Papaya crops areas present phytosanitary problems since neonicotinoid pesticides are currently applied without efficient control methods. It is necessary to study insects behavior associated with this type of crop in response to the use of the neonicotinoid thiamethoxam. In order to know the efficiency of this insecticide, different doses were evaluated for the control of the type of insects referred to below. The study area was the locality of Mata Tambor in Cotaxtla, Veracruz, Mexico. Where a plot of papaya "Maradol" of 2,778 plants ha-1 was established, applying different doses of thiamethoxam during the process: T1) $0 \mathrm{~kg} / \mathrm{ha}$; T2) $0.3 \mathrm{~kg} / \mathrm{ha}$; T3) $0.4 \mathrm{~kg} / \mathrm{ha}$; and T4) $0.6 \mathrm{~kg} / \mathrm{ha}$. The variables were: insect population, gross mortality rate and the identification of pests that cause damage to the crop. No significant statistical differences were found in insect populations when applying those different doses. The mortality rate 16 days after applying thiamethoxam was higher in $\mathrm{T} 3$ at a dose of $0.4 \mathrm{~kg} / \mathrm{ha}$, this response is attributed to the fact that the insecticide achieved a residual effect on the culture. The use of T2 with a dose of 0.3 $\mathrm{kg} / \mathrm{ha}$ in the crop became effective in pest control, generating a gross mortality rate of 241 individuals. Papaya cultivation can be associated with pests such as Bemisia tabaci, Myzus persicae, Frankliniella occidentalis and Toxotrypana curvicuada, which are the main vectors of virus in the culture.
\end{abstract}

Keywords: Thiamethoxam; Insects; Papaya.

Cite This Article: Juan Valente Megchún-García, María Del Refugio Castañeda-Chávez, Daniel Arturo Rodríguez-Lagunes, Jacel Adame-García, Joaquín Murguía-González, Fabiola LangoReynoso, and Otto Raúl Leyva-Ovalle. (2018). "USE OF THIAMETHOXAM, ASSOCIATED WITH INSECT POPULATIONS IN PAPAYA (CARICA PAPAYA LINNAEUS) 


\section{Introduction}

Papaya is one of the most important and profitable fruits in Mexico and Central America, during its cultivation there are many phytosanitary problems, which affects its level of production. In Mexico, the state of Veracruz stands out as the main producer of papaya with $19.7 \%$ of its total cultivated area, among its municipalities; the one that contributes the most is Cotaxtla with $21.29 \%$ of its total cultivated area [20]. Papaya "Maradol", Carica papaya cv. Maradol, is susceptible to the impact of external factors during the handling of the harvest, in addition, it systemically presents damages caused by Papaya ringspot virus (PRSV), which is transmitted by the pests of vegetable crops, also by close plantations of papaya contaminated and infested with pests and diseases [10]. There are different and numerous pests in the crop, among them, the aphids stand out for causing severe damages, some of them being difficult to control. Decisionmaking for its control is difficult because these species cannot be easily distinguished [28].

Other pests are mites Tetranychus merganser that is distributed mainly in the central area of the state of Veracruz [27]. Producers use for their control, among others, insecticides such as Imidacloprid, Amitraz and Abamectina, Methamidophos, Avermectina for agronomic management, which until now have shown not to be as efficient, since there is still a reduction in leaf area in papaya plants. Currently, producers in Mexico, India and Brazil are using insecticides from the chemical group of neonicotinoids. These insecticides are transported from the stomata to the root, and can be present in all the organs of the plant such as stems, leaves, fruits, as well as moving from the phloem and the xylem. The indiscriminate use and high doses in crops can cause ecological damage to the ecosystem, such is the case of the state of Sinaloa, Mexico, where around 118 active ingredients of pesticides have been applied in vegetables, among which the group of neonicotinoids stands out, mainly by the following: Acetamiprid, Clotianidin, Dinotefurán, Imidacloprid and Thiamethoxam. Although in Mexico the use of these insecticides is allowed, it is necessary to regulate and dose its use [18, 19, and 7].

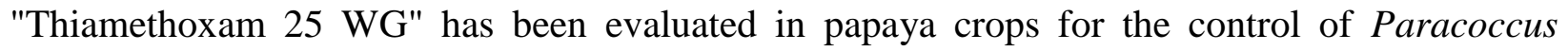
marginatus, finding as a result, that the dose of $62.50 \mathrm{~g}$ a.i/ha is efficient for the control of this pest [30]. Thiamethoxam is also used in tropical fruit trees for the control of Bemisia tabaci, Leptinotarsa decemlineata and Myzus persicae [31]. During 5 years, in the main papaya producing area in Veracruz, Mexico, 6\% of producers have used thiamethoxam for the control of aphids, whitefly and mites in papaya and vegetables cultivation, the application volume ranges around $3 \mathrm{~L} /$ ha per cycle [20].

The use of neonicotinoids such as thiamethoxam is efficient in the control of pests that damage tropical flowers and fruits [26]. In Mexico, the use of this insecticide is not restricted in papaya and other crops, despite this, it is recommended due to its systemic and contact mode of action for the control of pests in tropical fruit trees such as papaya [19]. There is a precedent that during the cultivaton, producers have carried out pest and disease control empirically, without any validation of application doses of neonicotinoid pesticides. Therefore, it is necessary to make a diagnosis to identify the main pests that are associated with the crop and establish annual defense 
programs [17]. Ecological risks to the ecosystem due to the massive use of insecticides are mainly because, when applied, there is no proper control and management of chemical insecticides in crops. Insecticides are subject to a series of transformations at a physical, chemical and biological level, standing out for the adsorption on soils and plants, volatilization, photolysis and chemical or microbial degradation. Its molecules are transported through water and air in the environment over long distances, and when volatile insecticides such as neonicotinoids enter the atmosphere, they are carried back to soil and water by rainfall, falling elsewhere, causing damage to the ecosystem [11].

Studies show that thiamethoxam encapsulated in a drop of water, of $340 \mu \mathrm{m}$, volatilizes in 30 seconds and evaporates into the environment, so that it could cause damage to other crops established in the area where it is used, or in its case, to human settlements established in close by areas.

The continuous exposure to the massive use of systemic and contact insecticides such as thiamethoxam or any insecticide of the chemical group of neonicotinoids, can cause damage to public health and ecological systems. Therefore, ecological risk studies are necessary, as well as defining the optimal doses for their use and management in agricultural crops [2]. With the above, this study seeks to achieve excellent phytosanitary control. In addition, by knowing the optimal dose of thiamethoxam for the control of pests, this insecticide can be part of the integrated management of pests and diseases of the papaya crop. Reason why this study was aimed at evaluating different doses of thiamethoxam to control insects associated with the cultivation of papaya.

\section{Materials and Methods}

The work was carried out in Mata Tambor, in the municipality of Cotaxtla, Veracruz, Mexico, located between the coordinates of $18^{\circ} 53^{\prime} 51^{\prime \prime}$ north latitude and $96^{\circ} 22^{\prime} 37^{\prime \prime}$ west longitude, in a "Maradol" papaya plot, with a population density of 2,778 plants/ha. The field seedlings were established on August 2, 2017 (Figure 1).

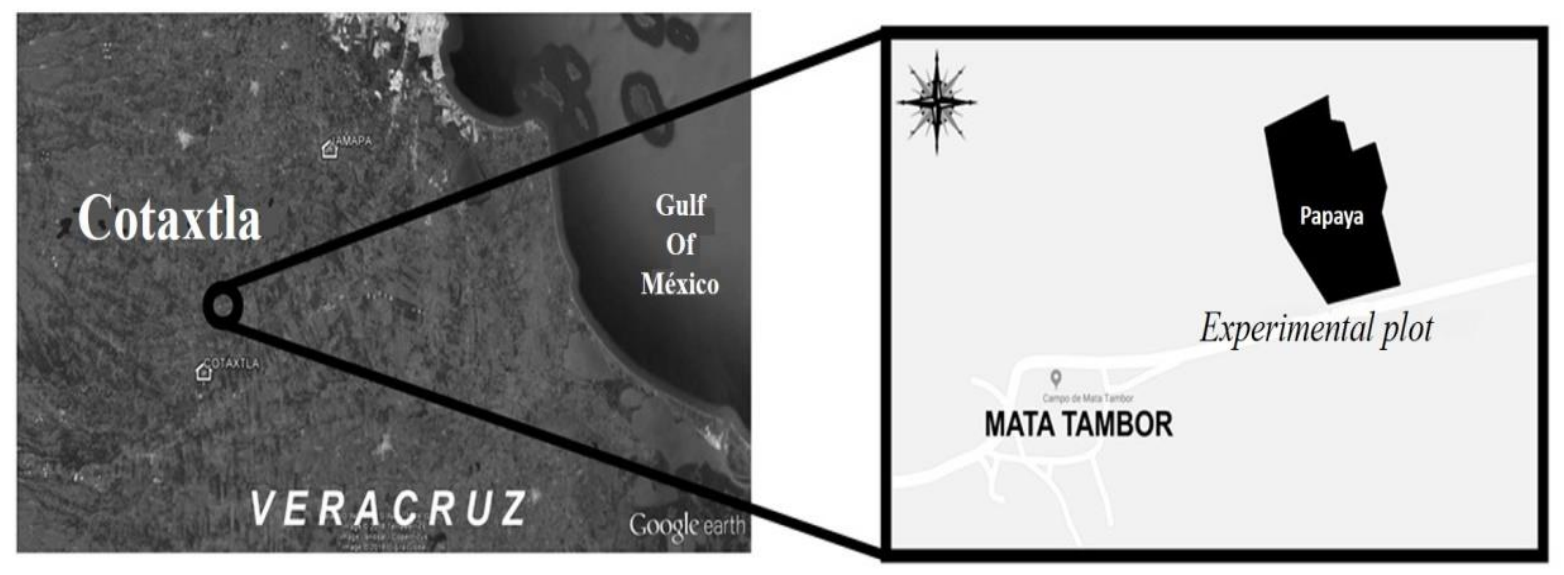

Figure 1: Mata Tambor, municipality of Cotaxtla, Veracruz, México 
The papaya plot was conducted in a traditional way with a drip irrigation system. Field trips were made, every eight days, to monitor the presence of pests in papaya crops. It was also applied, every 15 days, a liquid foliar fertilizer "Biocol" (N, NH4, NA, S, P, K, CA, MG, Acetic acid, Gibberellins, Purines, Thiamin, Folic Acid, Pantothenic Acid and Organic Acaricide) for fruit trees to correct the nutritional deficiencies of the crop. In addition, they were also fertilized with nitrogen, phosphorus and potassium, and with glyphosate and paraquat for the control of weeds. Applications of organic fertilizers based on sulfur and calcium were also carried out as part of the agronomic management.

After 78 days in the field, damage caused by pests was identified, designing then an experiment to evaluate the effectiveness of the insecticide thiamethoxam for the control of insect pests, using for this purpose, yellow traps with a dimension of $2,400 \mathrm{~cm}^{2}$. Two yellow traps were placed per experimental plot of papaya, the experimental plot consisted of three rows with papaya plants established at $1.20 \mathrm{~m}$ between plants and three meters between rows, each row is made up of 30 papaya plants. Treatments (T) evaluated for thiamethoxam were: $\mathrm{T} 1=0 \mathrm{~kg} / \mathrm{ha} ; \mathrm{T} 2: 0.3 \mathrm{~kg} / \mathrm{ha}$; T3: $0.4 \mathrm{~kg} / \mathrm{ha}$; T4: $0.6 \mathrm{~kg} / \mathrm{ha}$.

The management of the experiment consisted in comparing the population of insect pests of three experimental papaya plots; one handled with the use of yellow traps, the second with the use of thiamethoxam insecticide applied at 8 days and, finally, with the use of thiamethoxam applied at 15 days. For the process, first the yellow traps were placed in each plot, then, after eight days, it was made the first count of insect populations in each trap. Later, different doses of thiamethoxam were applied to control the populations of insects present in the crop, using for this an electric spray backpack model WS-15D, with an expense of $0.8 \mathrm{~L} / \mathrm{min}$. Subsequently, the count of insect populations was done 8 and 16 days after the insecticide was applied.

The Gross Mortality Rate of insect population was estimated, to perform GMR $\left(\mathrm{d}^{\mathrm{z}}\right)$ calculation the following formula was applied, according to the INEI ([16].

$\mathrm{d}^{\mathrm{z}}=\frac{\mathrm{D}^{\mathrm{z}} * 1000}{\mathrm{~N}}$

Where:

$\mathrm{d}^{\mathrm{z}}$ : Gross Mortality Rate

$\mathrm{D}^{\mathrm{z}}$ : Deaths that occurred

$\mathrm{N}$ : Estimated population

The experimental design was randomized blocks with four repetitions, and the gross mortality rate was estimated. In order to know the pest species associated with the crop, the different pests were collected and transferred to the Technological Institute of Ursulo Galván located in the municipality of Ursulo Galván, Veracruz. The identification of the pests was with a stereoscopic microscope using the help of taxonomic keys for their identification. The following indices were measured: Margalef Species Richness $(\mathrm{Dmg})=\mathrm{S}-1 / \mathrm{In} \mathrm{N}$; the Shannon's diversity and the Simpson's dominance $(\lambda)=\Sigma \mathrm{pi}^{2}$; the data was analyzed with the PAST software (version 2.03), 1999-2010. Also, an analysis of variance and means comparison tests were performed, using the Tukey test with a $\alpha$ of $\mathrm{P} \leq 0.01$, as well as nonparametric and parametric analysis of the data with the software STATISTICA (version 2007). 


\section{Results and Discussions}

The results obtained for the treatments applied with different doses of thiamethoxam in the papaya crop did not show significant statistical differences (Figure 2). Whereas16 days after the application of the insecticide, it was observed a decrease in the populations of the insects associated with the papaya crop. The greatest amount of insects present in the crop was eight days after having applied the different doses of the thiamethoxam. This response is attributed to the residual effect of the product applied to the foliage. In addition, there are similar reports in India that demonstrate the effectiveness of thiamethoxam in the control of Paracoccus marginatus in papaya plantations, 7 days after the insecticide was applied in the field [3]. Other studies report that in the first 74 hours of application in the plant, it causes mortality within a range of between $40 \%$ and $90 \%$ of the population of insects present, which are vectors of the virosis in papaya [4].

Eight days after applying a dose of $0.6 \mathrm{~kg} / \mathrm{ha}$ of thiamethoxam to the papaya plants, a population of insects higher than the other treatments was counted. However, sixteen days after applying this insecticide, the insect population present was $72.3 \%$ lower than the total number of insects present eight days after application. When applying doses of 0.3 and $0.4 \mathrm{~kg} / \mathrm{ha}$ of thiamethoxam in papaya plants, it was observed that the insect populations were lower than when only yellow traps were used (Figure 2). Studies conducted in Brazil on the coffee leaf miner (Leucoptera coffeella), demonstrated the efficiency in the control of this pest, in response to the fact that this systemic insecticide is translocated from the root to the aerial part of the plants, it is also reported that residues have been found in leaves even up to 150 days after being applied [8].

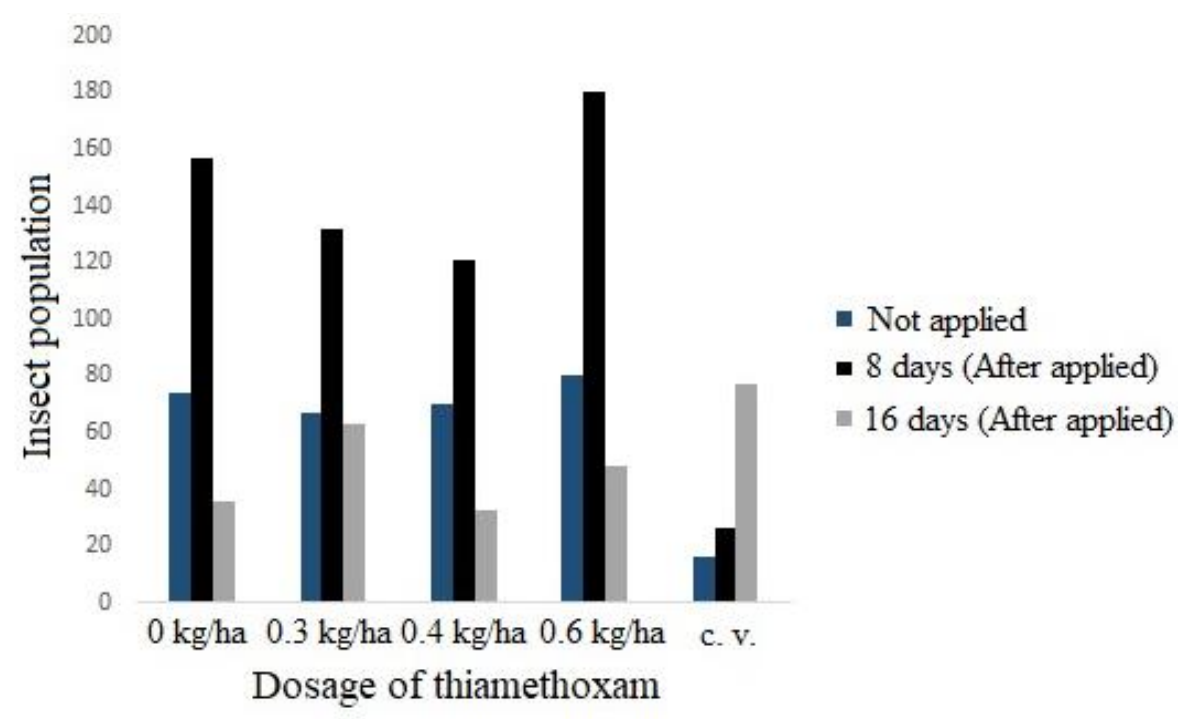

Figure 2: Effectiveness of the different doses of thiamethoxam insecticide on insect populations

With respect to the Gross Mortality Rate, the highest mortality was using the dose of $0.4 \mathrm{~kg} / \mathrm{ha}$, surpassing the mortality rate present with doses of 0.3 and $0.6 \mathrm{~kg} / \mathrm{ha}$ of thiamethoxam (Figure $3 \mathrm{a}$ y $3 b)$. 


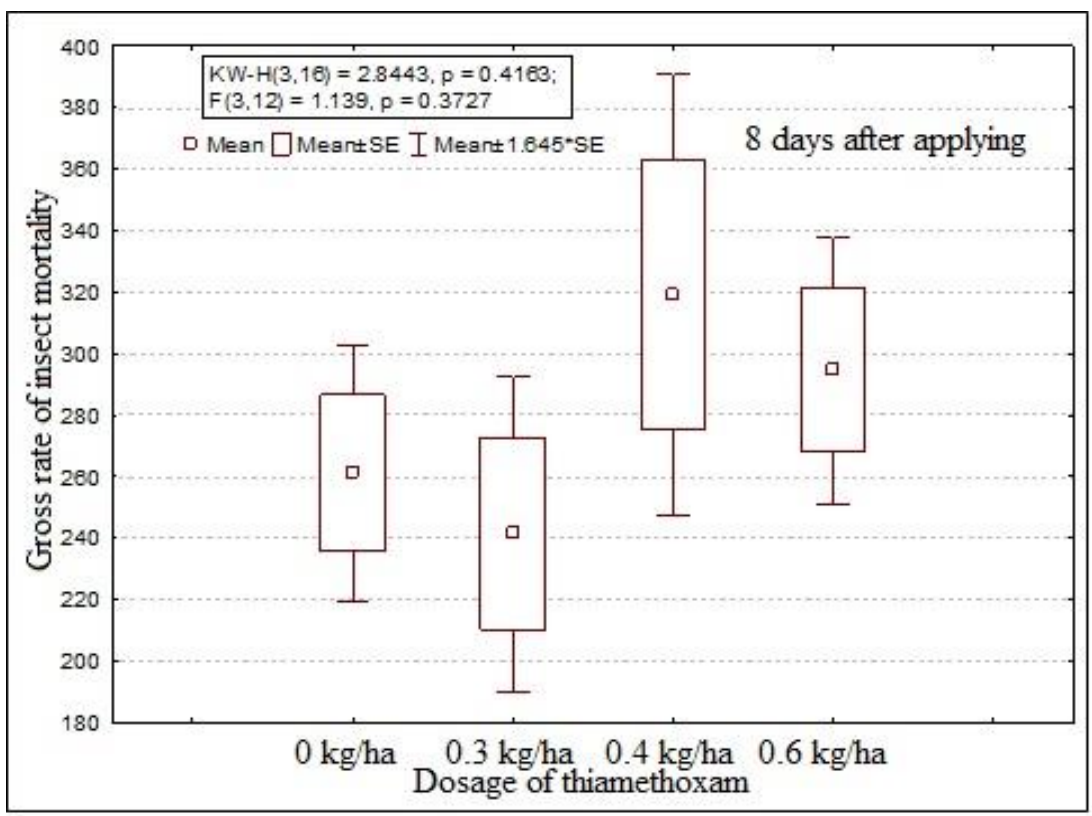

Figure 3a: Insects gross mortality rate in different thiamethoxam treatments, 8 days after applied to papaya foliage

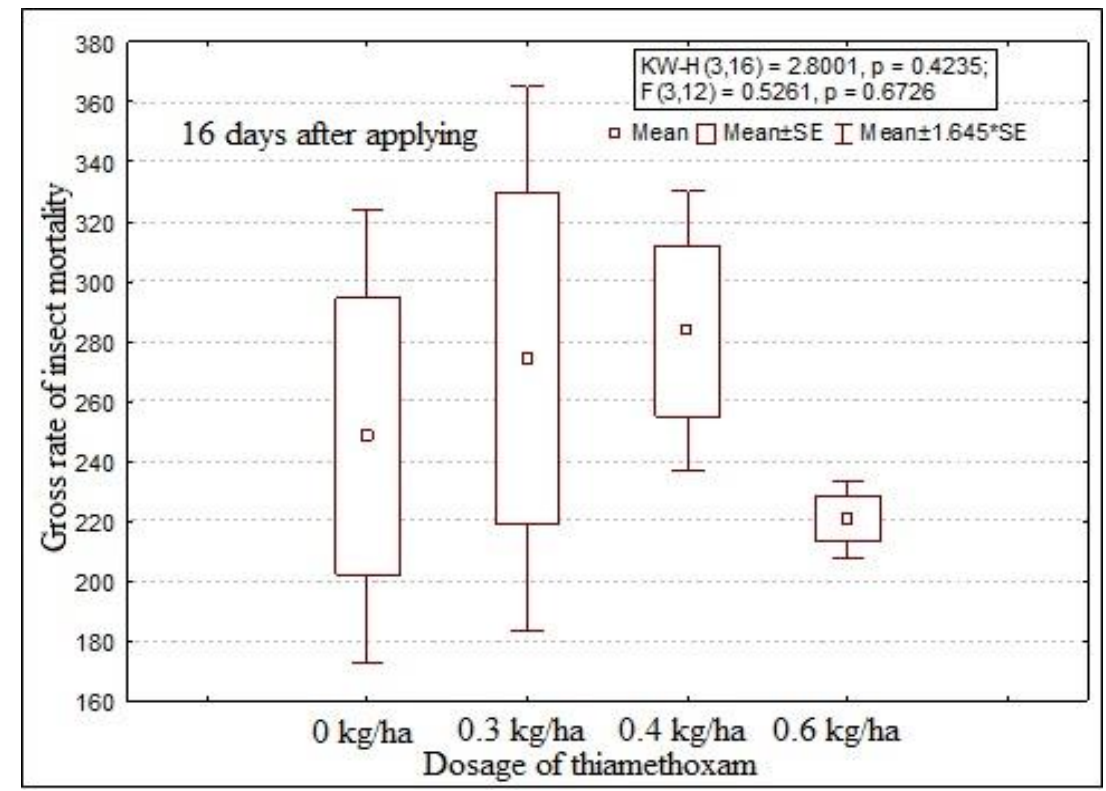

Figure 3b: Insects Gross Mortality Rate in different thiamethoxam treatments, 16 days after applied to papaya foliage

When thiamethoxam is applied every 8 days, a greater population of insects can be controlled, than when only yellow traps are used. With respect to the gross mortality rate of insects and pests, when applying thiamethoxam every 15 days, it is possible to achieve a better effectiveness if applied to the foliage of papaya plants (Table 1).

The behavior of the values of the Gross Mortality Rate in insects (Table 1), is similar to that when thiamethoxam is applied at 8 and 16 days, this response is attributed to the fact that the 
insecticide achieves a residual effect on the papaya cultivation. In evaluation studies of thiamethoxam with other insecticides Acetamiprid, Imidacloprid, Fipronil, Lambda cyhalothrin and Malathion, it was shown that thiamethoxam and Imidacloprid are more toxic on Myzus persicae (Sulzer) for an LC50 of 4.1 and $4.5 \mathrm{mg} / \mathrm{kg}$ [12]. The population of these pests was reduced 16 days after the application of thiamethoxam. With respect to Simpson's Dominance Index between individuals, the pests present, 15 days after applying the thiamethoxam, showed a higher value than the individuals in the treatments with yellow traps and the treatments where thiamethoxam was applied after 8 days. With regard to Shannon's Diversity Index, the values for all treatments were lower than the normal value of 2 , however for the dominance index (Simpson's Index) the highest value that was 1,384 was present using only yellow traps. Similar case with the Simpson's Index of 0.7489. Otherwise, with thiamethoxam applied every 15 days, where the Margalef Species Richness index was 0.5777 higher than the others, this means that there was more than one species of pest associated with the papaya crop (Table 1). This may be due to the presence of habitats with more complex structures that are close to papaya farms, which increase its biodiversity and, in turn, the density of pest species and its population [13].

The greatest diversity of insects occur in mixed or forest crops, which can cause problems and economic losses when there are numerous groups of pests, among them we can mention, Luebea senmanii and Anacardium excelsum, in addition to having some relationship with the phenology of the crops [29].

Table 1: Residual effect of thiamethoxam on insect populations present in papaya culture

\begin{tabular}{|c|c|c|c|c|c|c|}
\hline $\begin{array}{c}\text { Thiamethoxam } \\
\text { applied }\end{array}$ & $\begin{array}{c}\text { No. of } \\
\text { individuals }\end{array}$ & $\begin{array}{c}\text { Gross } \\
\text { mortality } \\
\text { rate+(d } \mathbf{d}^{\mathbf{z}}\end{array}$ & Dominance & $\begin{array}{c}\text { Shannon's } \\
\text { Index }\end{array}$ & $\begin{array}{c}\text { Simpson's } \\
\text { Index }\end{array}$ & $\begin{array}{c}\text { Margalef's } \\
\text { Index }\end{array}$ \\
\hline $\begin{array}{c}\text { Control (Yellow } \\
\text { traps) }\end{array}$ & $73 \mathrm{~b}$ & 247 & 0.2511 & 1.384 & 0.7489 & 0.5288 \\
\hline $\begin{array}{c}8 \text { days after } \\
\text { applying }\end{array}$ & $147 \mathrm{a}^{* *}$ & 249 & 0.256 & 1.374 & 0.744 & 0.4702 \\
\hline $\begin{array}{c}15 \text { days after } \\
\text { applying }\end{array}$ & $45 \mathrm{~b}$ & 250 & 0.2672 & 1.353 & 0.7328 & 0.5777 \\
\hline
\end{tabular}

Different letters, represent significant differences.

Populations of insect pests that cause damage to the papaya crop were identified, such as whitefly, citrus green aphid, thrips, papaya fruit fly and fruit fly (Figure 3). The importance of controlling these pests is that, nowadays, the presence of virosis in papaya crops is a problem that can cause up to $100 \%$ damage in new plantations in production.

Insects vectors, such as Bemisia tabaci, are responsible for the damage by virosis in papaya crops, as well as the presence of Diabrotica sp.; since contamination by virosis is related to the presence of sucking insects. Similar case was in the whitefly control, where the adult population was reduced from $36 \%$ to $97 \%$ between 3 and 14 days after thiamethoxam applications [1]. It was found in seedling production, that the use of thiamethoxam, with frequencies between seven and ten days, can protect the seed from any contamination by pathogens such as Rhizoctonia sp., Macrophomina phaseolina (Tasis) and Colletotrichum sp. [1]. 
The resistance of Bemisia tabaci and the citrus aphid (Myzus persicae) to Imidacloprid and other insecticides of the group of neonicotinoids, can be effectively controlled in $87 \%$ and $83 \%$, at 2 and 7 days after applying thiamethoxam, with a dose of $0.5 / 1$ of water per hectare, to the papaya crop. In addition, the residual effect of thiamethoxam can control aphids for 20 days with efficiency greater than $70 \%$ [5].

The thiamethoxam combined with fungicides, can reduce the populations of Bemisia tabaci and consequently the incidence by virosis. The presence of the fruit fly and the papaya fruit fly (Toxotrypana curvicauda) were also identified, both cause severe damage to flowers and fruit, which is why their control is necessary to reduce damage to the commercialization of the fruit. Other species of pests that are of economic importance for the papaya crop were identified, such as the presence of Laspeyre siapomonella, so it is necessary to continue its study to know the possible damages to the crop. It is important to mention that there was no mortality of bees (Apis mellifera) in association with the papaya crop.

\begin{tabular}{|c|c|c|c|c|c|}
\hline Common name & Scientific name & Insects & Common name & Scientific name & Insects \\
\hline Lady bug & Diabrotica sp. & & Cigarrinha verde & Nezara vïridula & \\
\hline Moth & Laspeyre siapomonella & & Jadera coturnix & $\begin{array}{c}\text { Anthocoris } \\
\text { nemoralis }\end{array}$ & \\
\hline Thrips & Frankliniella occidentalis & & Mealy bug & Planococcus spp. & \\
\hline Green citrus aphid & Myzus persicae & & Fruit fly & $\begin{array}{c}\text { Anastrepha ludens } \\
\text { Loew }\end{array}$ & \\
\hline White ffy & Bemisia tabaci & & Papaya fiuit fly & $\begin{array}{c}\text { Toxotrypana } \\
\text { curvicauda }\end{array}$ & \\
\hline
\end{tabular}

Figure 3: Insects identified in the laboratory, associated with the cultivation of papaya in the town of Mata Tambor, in the municipality of Cotaxtla, Veracruz, Mexico

Thrips, which is a potivirus vector, is another of the insects associated with the cultivation of papaya. For the control of thrips (Frankliniella schultzei Trybom) in tomato crops, in Sao Paulo, Brazil, a dose of 150 to $200 \mathrm{~g}$ i.a. ha ${ }^{-1}$ of thiamethoxam was evaluated, applied in a drench form, with efficiency higher than $93 \%$ and a residual effect of 24 days [25]. The Diabrotica bivitulla and Diabrotica speciosa in Brazil are one of the main vectors of the Papaya Lethal Yellowing Virus (PLYV) [23]. A similar case occurs with the presence of Diabrotica sp. and the damages caused by virosis to young papaya plantations in the municipality of Cotaxtla, Veracruz. Considering, that there is a relationship between the age of the plant at the moment of being infected, with the speed of viral dispersion; the use of anti-aphids meshes in the nursery stage is necessary, in order to protect the papaya plants from the damages caused by the vectors of the virus. 
In Cuba, the use of anti-aphid mesh in papaya plantations has reduced the severity of the Papaya Ring Spot Virus (PRSV) by 30\%. The use of plant barriers also protects the plantations of Maradol Roja (Carica papaya var. Maradol Roja) and reduces the damage caused by pests [6]. The fruit fly and the papaya fruit fly identified in papaya plantations can be monitored more efficiently with the use of cylindrical traps made with opaque green plastic and the use of synthetic pheromone. In the case of the fruit fly (Anastrephae ludens), the main infestations come from the trees of the genus Spondeias that are located near papaya crops [15, 21].

For adult fly capture and monitoring, the use of McPhail traps baited with corn hydrolyzed protein is recommended, as well as applications of low toxicity chemical insecticides at the right time [24]. In the case of the Laspeyre siapomonella, this insect can cause damage to the papaya flower up to $100 \%$ in severe infestations [9]. Currently in European countries and in the United States, the use of neonicotinoids has been restricted by the phenomenon called Collapse of the Beehives, this means that the massive use of these products caused the death of bees that pollinated tropical fruit trees [19]. The pollination of fruit trees is carry out by bees in $80 \%$, there are also other insects such as the order of Coleoptera (Cantarophyll) and Diptera, among them the flies (myophyl) which are associated with the pollination of crops. Therefore, it is necessary that chemical insecticides do not generate a severe toxicity to the main natural pollinators of crops [22].

To reduce the ecological risk due to the use of thiamethoxam, it is necessary to carry out low dose applications of this insecticide for the control of pests, in this sense to reduce damage to soil, water, environment and public health. Considering also combining them with other sustainable technologies in the cultivation of papaya, such as the application of biofertilizer based on mycorrhizae (Glomus intraradices), by doing this, the nutrition of the crop is improved and consequently, the stress of the plant is reduced, decreasing vulnerability to the presence of pests [14].

\section{Conclusions and Recommendations}

The use of thiamethoxam is efficient and recommended if applied to the foliage in a controlled dose of $0.3 \mathrm{~kg} / \mathrm{ha}$. Through this application, the residual effect of thiamethoxam, in a 16-day time interval, reached a gross mortality rate of 241 individuals. According to this dose of concentration and time of exposure, populations of pests such as Bemisia tabaci, Myzus persicae, Frankliniella occidentalis and Toxotrypana cuirvicauda are reduced in the cultivation of papaya (Carica papaya Linnaeus).

When applying thiamethoxam to the foliage with a dose of $0.3 \mathrm{~kg} / \mathrm{ha}$, it prevents the appearance of a lower diversity of individuals from pest populations, coming from nearby farming systems. When low doses are used in the soil, damage to the macrofauna and microflora is reduced, the concentration of thiamethoxam in the papaya fruit is lower and, in turn, fruit with quality and safety for its consumption.

Another important aspect is to use the appropriate dose of thiamethoxam in the culture, since due to its high solubility in water, the use of low doses helps to reduce ecological risks. Mainly when 
this pesticide participates in the runoff processes that contaminate surface waters of aquatic systems

\section{Acknowledgements}

To the Tecnológico Nacional de México/Instituto Tecnológico de Boca Del Río, for the budgetary allocation of the call for support for scientific research and technology 2017.

To Universidad Veracruzana campus Córdoba; Biological and Agricultural Sciences Faculty. And, to the Consejo Nacional de Ciencia y Tecnología de México (CONACYT). For the allocation of the doctoral scholarship No. 291025.

\section{References}

[1] Almándoz P. J. E., Rodríguez M. F., Palacios A. J., Díaz R. J. A (2009). Efectividad biológica del fungicida/insecticida thiamethoxam 20\%+ difenoconazol 20\% +mefenoxan 2\% PS, sobre insectos y enfermedades en frijol (Phaseolus vulgaris Lin). Fitosanidad; Vol. 13, No.3: pp. 211216.

[2] Arantes R. da C. J. P., Lasmar O., Magri P. R. A., Sousa A. G. 2001. Evaporation time of droplets containing thiamethoxam and adjuvants sprayed on sugarcane leaves. Pesquisa Agropecuaria Tropical; Vol 46, No. 1: pp 1-8.

[3] Basana G. G., Vijay K. L., Jagadish K. S., Kandakoor S. B. y Rani A. T., 2013. Efficacy of insecticides against papaya mealybug, Paracoccus marginatus Williams and Granara de Willink (Hemiptera: Pseudococcidae). Current Biotica: Vol 7, No.3: pp. 161-173.

[4] Batista F. A., Almeida J. E. M. y Lamas C., 2001. Effect of thiamethoxam on Entomopathogenic microorganisms. Neotropical Entomology: Vol. 30, No. 3: pp. 437-447.

[5] Beltrán R. E., Helman S., Garay F., Lescano A., Peterlin O. 2006. Eficacia de insecticidas aplicados al follaje en el control de aphis gossypii glover en algodón. Revista de Investigaciones Agropecuarias. Vol. 35, No.1:pp. 135-141.

[6] Cabrera M. D., García H. D., Caballero A. M. W., García M. P. L., Portal V. O. 2011. Manejo la Mancha Anular de la papaya mediante el uso de malla antiáfidos en viveros de Carica papaya L., Var. Maradol Roja. Fitosanidad. Vol. 15, No.4: pp. 241-244.

[7] Castañeda C. M. del R., Lango R. F., Navarrete R. G., 2018. Hexachlorocyclohexanes, Cyclodiene, Methoxychlor and Heptachlor in sediment of the Alvarado Lagoon System in Veracruz, México. Sustainability, Vol. 10; No.76: pp. 1-14. Doi: 10.3390/su10010076.

[8] Diez R. G. 1., Baptista G. C., Trevizan L. R. P., Haddad M. L., e Nava D. E. 2006. Residuos de thiamethoxam, Aldicarbe e de seus metabólitos em folhas de cafeeiro e efeito no controle de Leucoptera coffeella (Guérin-Meneville) (Lepidoptera: Lyonetiidae). Neotropical Entomology. Vol 3, No. 2: pp 257-263.

[9] Domínguez G. O. E. 1983. Insectos perjudiciales del guanábano (Annona muricata L.) en el estado de Zulia, Venezuela. Revista de la Facultad de Agronomía. Vol 6, No. 2: pp 699-707.

[10] Flores O. A., Marín H. F., Zapata J. A. 2009. Estudio de las prácticas de cosecha y poscosecha de la papaya (Carica papaya cv. Maradol), en el Departamento del Huila, Colombia. Revista de Investigación Agraria y Ambiental; Vol. 0, No. 1: pp 29-36.

[11] García G. C., Rodríguez M. G. D. 2012. Problemática y riesgo ambiental por el uso de plaguicidas en Sinaloa. Ra Ximhai; Vol. 8, No. 3: pp 1-10.

[12] Gavkare O., Kumar S., Sharma N. y Sharma P. L. 2013. Evaluation of some novel insecticides (SULZER). THE BIOSCAN, an international quarterly journal of life sciences: Vol. 8, No. 3: pp 1119-1121. 
[13] González F. M. L., Jahnke S. M., Morais R. M., Da Silva G. S., 2014. Diversidad de insectos depredadores en áreas orizícola orgánica y de conservación, en Viamao, RS, Brasil. Revista Colombiana de Entomología: Vol. 40, No. 1: pp120- 128.

[14] Guillen S. D., Vázquez R. S., Alía T. I., López M. V., Andrade R. Ma., Juárez L. P., Hernández P. R. y Hernández A. Ma. 2017. Biofertilization with Glomus intraradices and Azospirillum brasilense to improve the quality of papayo plantule. Global Advanced Research Journal of Agricultural Science: Vol. 6, No. 5: pp 114-118.

[15] Health R. R., Epsky N. D., Jiménez A., Dueben B. D., Landolt P. J., Meyer W. L., Aluja M., Rizzo J. 1996. Camino M., Jerónimo F. y Baranowski. Improved pheromone-based trapping systems to monitor Toxotrypana curvicauda (Diptera: Tephritidae). Florida Entomologist: Vol. 79, No. 1: pp 37-48.

[16] INEI, 2000. Metodologías para el cálculo de los indicadores de Mortalidad. Colección de metodologías estadísticas del INEI (Instituto Nacional de Estadística e Información) de Perú. No. 08: 9p. Url: http://www.inei.gob.pe.

[17] Jiménez J. S. F. 2007. La señalización y el pronóstico de plagas. Origen desarrollo y retos. Fitosanidad: Vol. 11, No. 3: 51-56.

[18] Leyva M. J. B., García de la P. L. Ma., Bastidas B. P. de J., Astorga R. J. E., Bejarano T. J., Cruz H. A., Martínez R. I. E. Betancourt L. M. 2014. Uso de plaguicidas en un Valle agrícola tecnificado en el noreste de México. Revista Internacional de Contaminación Ambiental: Vol. 30, No. 3: pp 247-261.

[19] Megchún G. J. V., Castañeda C. Ma. del R., Rodríguez L. D. A., Murguía G. J., Lango R. F., Leyva O. O. R., 2016. Thiamethoxam in Tropical Agroecosystems. Global Journal of Biology, Agriculture \& Health Sciences: Vol. 5, No. 3: 75-81.

[20] Megchún G. J. V., Rodríguez L. D. A., Castañeda C. Ma. del R., Murguía G. J., Lango R. F., Leyva O. O. R., 2017. Thiamethoxam in papaya (Carica papaya Linnaeus). Agroecosystems. International Journal of Environment, Agriculture and Biotechnology. Vol. 2, No. 2: pp 874-880. http://dx.doi.org/10.22161/ijeab/2.2.40

[21] Murillo F. D., Liedo P., Nieto L. G., Cabrera M. H., Barrera J. F., Montoya P. 2016. First instar larvae morphology of oppinae (Hymenoptera: Braconidae) parasitoids of Anastrepha (Diptera: Tephritidae) fruit flies. Implications for interspecific competition. Arthropod Structure \& Development: Vol. 45: pp 294-300. Doi: 10.1016/j.asd.2016.01.003.

[22] Nuñez A. L. A., Carreño J. I. 2017. Polinización por abejas en Syagrus orinocensis (Arecaceae) en la Orinoquia Colombiana. Acta Biológica Colombiana. Vol. 22, No. 2: pp 221-233.

[23] Pereira A. J., Alfenas Z. P., Cascardo R. S., Andrade E. C., Murilo Z. F. 2012. Analysis of the full-length genome sequence of papaya lethal yellowing virus (PLYV), determined by deep sequencing, confirms its classification in the genus Sobemovirus. Archives of Virology: No. 157: pp 2009-2011. Doi 10-1007/s00705-012-1384-x.

[24] Quintero E. M., López I. C., Kondo T. 2012. Manejo integrado de plagas como estrategia para el control de la mosca del botón floral del maracuyá Dasiops inedulis Steystal (Diptera: Lonchaeidae). Revista Corpoica-Ciencia y Tecnología Agropecuaria. Vol. 13, No. 1: pp 31-40.

[25] Raetano C. G., Kobayashi M. R., Kuwahara W. R., Vinchi R. R. 2003. Application methods and dosages of thiamethoxam in thrips control on tomato plants. Horticultura Brasileira, Brasilia. Vol. 2, No. 3: pp 429-432.

[26] Raga A., Eidi S. M., 2011. Toxicity of neonicotinoides to Ceratitis Capitata and Anastrepha fraterculus (Diptera: Tephritidae). Journal of Plant Protection Research: Vol. 51, No. 4: pp 413419.

[27] Reyes P. N., Villanueva J. J. A., De la Cruz V. M., Cabrera M. H., Otero C. G., 2013. Parámetros poblacionales de Tetranychus merganser Boudreaux (Acari: Tetranychidae) en papayo (Carica papaya L.) a diferentes temperaturas. Agrociencia. No. 47: pp 147-157. 
[28] Robles W., Pantoja A., Abreu E., Peña J., Ortiz J. Lugo Ma. de L., Cortes M., Macchiavelli R. 2006. El efecto de prácticas agronómicas sobre el nivel poblacional de áfidos y virosis en Carica papaya L. Manejo Integrado de plagas y Agroecología (Costa Rica). No. 77: pp 38-43.

[29] Santos M. A., Barrios H. E., Luna I. G., 2009. Diversidad de insectos en cuatros especies de plantas maderables nativas establecidas en monocultivos en Sardinilla, Panamá. Entomotropia. Vol. 24, No. 1: pp 11-22.

[30] Seni A.; Sahoo AK. 2015. Efficacy of certain insecticides on papaya mealybug, Paracoccus marginatus Williams y Granara de Willink (Hemiptera: Pseudococcidae). Journal of Entomology and Zoology Studies: Vol. 3, No. 4: pp 14-17.

[31] University the Hertfordshire, 2015. PPDB: Pesticide properties database. http://sitem.herts.ac.uk/aeru/footprint/es/Reports/631.htm.

*Corresponding author.

E-mail address: juanmg_3@ hotmail.com/ castanedaitboca@ yahoo.com.mx 